\title{
An Indian Ocean dilemma: Sino-Indian rivalry and China's strategic vulnerability in the Indian Ocean
}

\author{
David Brewster * \\ Strategic and Defence Studies Centre, Australian National University, Level 3, Hedley Bull Centre, \\ Building \# 130, Garran Road, Canberra, ACT 0200, Australia

\begin{abstract}
This paper looks at the key strategic issues faced by China in the Indian Ocean within the context of growing Sino-Indian rivalry. It makes two basic arguments: first, that China has considerable strategic disadvantages in the Indian Ocean as compared with India; and second, that India has had more success than China in developing security relationships in the region. These propositions differ from a more common narrative, according to which China is establishing security relationships throughout the region that seriously threaten India. This paper argues that, on the contrary, China faces a strategic dilemma right across the Indian Ocean that it will only be able to partially mitigate in the short to medium term. Perhaps we should be asking how China's strategic vulnerability should be best managed.
\end{abstract}

Keywords: India; China; strategic competition; Indian Ocean

On 27 January 2014, a Chinese naval action group, including China's largest amphibious landing ship, the Changbaishan, and two modern destroyers, Wuhan and Haikou, steamed south through the Sunda Strait into the Indian Ocean. The Chinese vessels conducted a brief series of exercises in international waters between the Indonesian island of Java and Australia's Christmas Island, almost certainly within the Indonesian or Australian EEZs, and then returned to the Pacific via the Lombok Strait (Medcalf, 2014). This unannounced exercise was the first of its kind by China's PLA Navy in the eastern Indian Ocean, and was intended to demonstrate China's capabilities against a sophist-icated naval adversary - as official Chinese media later suggested, it involved 'quick response training for electronic war in the Indian Ocean' (CCTV.com, 2014).

The Chinese exercise was followed only a few days later by a large multilateral naval exercise hosted by the Indian Navy in the neighbouring Bay of Bengal. India's Exercise Milan 2014 involved vessels from 16 guest navies and coastguards from across the Indo-Pacific, including representatives from South Asia (Bangladesh, Sri Lanka and the Maldives); Southeast Asia (Myanmar, Thailand, Malaysia, Indonesia, Singapore, Cam-bodia and the Philippines); Australasia (Australia and New Zealand), and even a strong representation from the western Indian Ocean (Kenya, Mauritius, Seychelles and Tanzania). Exercise Milan is held biennially and is primarily an exercise in Indian maritime diplomacy, focusing on building relationships and confidence among the military maritime community of participating states.

*Email: dhbrewster@bigpond.com 
This paper uses these two recent naval exercises as a starting point to consider the key strategic dilemma faced by China in the Indian Ocean within the context of growing Sino-Indian rivalry. The balance of power in the Indian Ocean is changing quickly, driven by the erosion of the longstanding US strategic predominance and the rise of China and India as major powers. However, at least at present, strategic competition in this region appears to be much more pronounced between China and India than between either of those countries and the United States. The US has been the predominant power in the Indian Ocean for decades and might well be seen as a more known quantity. Indeed, many analysts see a significant danger of an increasing strategic contest between China and India in the Indian Ocean as they jostle for influence and position in ways reminiscent of US-Soviet rivalry during the Cold War (Kaplan, 2009; Mohan, 2012).

The paper makes two basic arguments: first, China faces major geostrategic disadvantages in the Indian Ocean as compared with India; and second, that compared with China, India has had considerable success in developing security relationships with the Indian Ocean states. Although China is seeking to develop strategic partners, few countries in the region would realistically see China as a security provider. These propositions differ from a more common narrative, under which a Chinese juggernaut is expanding its economic and political influence as a precursor to developing a security presence in the region that could threaten India. This paper argues that, on the contrary, China faces a strategic dilemma across much of the Indian Ocean that it will find difficult to resolve in the foreseeable future. Those concerned about the security dynamics of the region need to take this strategic vulnerability into account.

\section{China's geostrategic vulnerability in the Indian Ocean}

China faces profound strategic challenges in the Indian Ocean region, which it cannot easily overcome, and this will likely have a significant effect on the strategic dynamic between China and India. China's overwhelming strategic imperative in the Indian Ocean is the protection of its sea lines of communication (SLOCs) across the Indian Ocean, particularly the transport of energy. The most important of these SLOCs extends from the Strait of Hormuz at the mouth of the Persian Gulf, around the Indian subcontinent into the Bay of Bengal and through the Straits of Malacca. Other SLOCs extend across the Indian Ocean from Suez and from southern Africa. China is probably most vulnerable in the Malacca Strait, through which around 82\% of China's oil imports pass (US Department of Defense, 2012, p. 42). According to Chinese President Hu Jiantao this chokepoint represents China’s 'Malacca Dilemma' (Storey, 2006). China also faces the so-called 'Hormuz Dilemma' in the Persian Gulf, where some $40 \%$ of China's oil imports transit the Strait of Hormuz. Indeed, as will be discussed in this paper, China faces a dilemma across the entire Indian Ocean, where its SLOCs are highly vulnerable to threats from state and non-state actors.

China's strategic vulnerability in the Indian Ocean is principally a function of geography. The Indian Ocean is a largely enclosed ocean, with few entry points and vast distances between. The east-west sea lanes across the ocean, over which much of the world's energy is carried, are highly vulnerable to interdiction. This creates a strategic premium for those powers that are able to control the so-called 'chokepoints' and deny their rivals access to key ports. For more than 500 years, since the Portuguese adventurer and imperialist, Afonso de Albuquerque, transformed the Indian Ocean into a mare clausum (or 'closed sea') over which Portugal had exclusive jurisdiction, competing 
powers have jostled over control of the Indian Ocean chokepoints and the ports in between. The Indian Navy's 2007 Maritime Military Strategy expressly invokes Albuquerque's name to justify India's strategy of seeking control over the key entry and exit points to the Indian Ocean (Indian Navy, 2007, p. 59). In contrast, to India's position, China currently has no ability to exert control over any of these chokepoints and nor has it any regular naval presence in any of the ports between.

China's strategic vulnerability is reinforced by the scarcity of overland transport connections between it and the Indian Ocean. Formidable geographic barriers created by the mountain ranges, deserts and jungles along the southern edge of the Eurasian continent make the development of such links very difficult. Indeed, until well into the twentieth century, there were no major transport routes - roads, railways or rivers connecting China with the Indian Ocean. Even today, there are only a handful of tenuous north-south links across the southern Asian littoral. This disconnect has limited China's presence and influence in the region and further narrows China's strategic options. Virtually all of China's trade with Europe and the Middle East must cross the Indian Ocean, from west to east it must skirt the Indian subcontinent and transit Southeast Asia before landing at China's Pacific Ocean ports.

A combination of these factors means that in strategic jargon the Indian Ocean represents 'exterior lines' for China and 'interior lines' for India. The great triangle of Indian subcontinent that juts south from Eurasia dominates the entire northern Indian Ocean, giving India a natural centrality to the region. Geography provides India with considerable military advantages in the Indian Ocean, including short lines of communication to its own bases and resources. China has corresponding disadvantages, including the need to deploy its naval forces to the Indian Ocean through narrow and dangerous chokepoints and then cope with very uncertain logistical support when it arrives (Holmes, 2012). As a result, unlike other dimensions of strategic competition between India and China, the Indian Ocean is one area where India holds a clear military advantage over China. While there may be debate about the ultimate utility of India's ability to dominate Indian Ocean SLOCs, it is nevertheless still seen as a key bargaining chip. As the former Indian Chief of Naval Staff, Admiral Mehta, once commented, 'The weak area for China today is the Indian Navy. We sit in the Indian Ocean and that is a concern for China and they are not happy as it is not so easy for them to come inside' (Zeenews.com, 2009).

Indeed, the rarity of the PLA Navy actually 'coming inside' the Indian Ocean is demonstrated by reactions to the foray of the Chinese surface action group into the Indian Ocean in January 2014. Some analysts breathlessly claimed that the voyage demonstrated the PLA Navy's ability to 'break through' the first island chain - as if the Chinese vessels had broken some maritime blockade (Wroe, 2014). ${ }^{1}$ But one could also see the voyage as unremarkable: the ability of three Chinese ships to travel several thousand kilometres through international waters in the twenty-first century, just as ships have been doing for hundreds or thousands of years, should not be seen as an achievement of particular note. Indeed, the Chinese exercise only served to emphasise that the PLA Navy can only deploy to the Indian Ocean through a handful of narrow straits through the Indonesian archipelago - Malacca, Sunda, Lombok or Weitar - where its naval vessels can be tracked with relative ease and are highly vulnerable to interdiction. ${ }^{2}$

China is trying to mitigate its vulnerabilities in the Indian Ocean in several ways: first, through building capabilities to project limited naval and air power into the Indian Ocean; second, through gaining greater access for its naval vessels to ports in the Indian Ocean; 
and third, by developing limited overland transportation links to the Indian Ocean through Myanmar and potentially also Pakistan. But despite some of the rhetoric surrounding China's growing presence in the Indian Ocean, these do little to mitigate China's fundamental strategic disadvantages.

\section{China's naval modernisation}

In recent years, China has embarked on a major naval expansion programme that has the potential to change the naval balance of power in the Western Pacific (US Congressional Research Service, 2014). China's overall naval capabilities now exceed India's in quantitative and qualitative terms and this differential is likely to expand in the coming years. But, significantly, China's power projection capabilities in the Indian Ocean are limited and are likely to remain so in the foreseeable future (Yung, 2010). The PLA Navy has little experience in projecting power beyond coastal waters. Although it has made relatively small anti-piracy deployments in the Arabian Sea since 2008, these deploy-ments have not transformed the PLA Navy into a true blue water navy. Despite its naval expansion programme, it has a limited number of blue water naval combatants and limited long-range air strike capabilities. Even if it builds those capabilities, China's ability to project power into the Indian Ocean will be highly constrained by the long distance from Chinese ports and air bases. The closest Chinese naval base to the Indian Ocean is at Hainan Island in the north of the South China Sea. Its air bases in southern China are at long distances from the Indian Ocean and the PLA Air Force has limited mid-air refuelling capabilities (Perrett, 2011). These constraints are compounded by the lack of guaranteed logistical support facilities available to the PLA Navy in the Indian Ocean, and the need for Chinese naval vessels to deploy to the Indian Ocean through the narrow chokepoints through the Indonesian archipelago. For these and other reasons, many analysts argue that for the foreseeable future, China's core naval objective will be on sea-denial in the Western Pacific (Singh, 2013).

\section{China's string of pearls}

Some believe that China is seeking to mitigate its lack of naval bases or logistic support facilities in the Indian Ocean through what has been called the 'String of Pearls' strategy in which the PLA Navy will develop bases or have access to facilities across the northern Indian Ocean. Over the last decade or so, Chinese companies have been involved in the funding and construction of commercial port facilities at Gwadar (in Pakistan) and Hambantota (in Sri Lanka) and Kyaukpyu (in Myanmar). It is sometimes claimed that China has negotiated secret rights to allow the PLAN to develop a permanent presence in these ports when needed.

Since the term was coined in 2005, the String of Pearls narrative in its various forms has been a prominent factor in Indian public debate about China and its intentions in the Indian Ocean (Maitra, 2005; Ramachandran, 2007). But there are considerable doubts about whether these 'Pearls' would make good naval bases for China. According to some analysts, converting the ports of Gwadar and Hambantota into naval bases would require billions of dollars in investment in order to ensure their viability in wartime, and that their exposed position would make them difficult to defend, especially against an enemy equipped with long-range precision strike capability (Holmes \& Yoshihara, 2008; Kostecka, 2010). Nor would a permanent Chinese naval presence at these ports prevent 
the interdiction of Chinese energy supplies. Indeed to properly mitigate its vulnerabilities in the Indian Ocean, China would need to be able to defend the entire length of its SLOCs that run from inside the Persian Gulf around the Indian subcontinent and through the Malacca Straits. While any Chinese naval presence might have some defensive value, it would have limited offensive value for China, as any offensive actions would immediate expose China's long and vulnerable SLOCs to retaliatory measures.

Others argue that instead of trying to build naval bases, China will instead pursue a 'places not bases' strategy. This term refers to the post-Cold War strategy of the United States of seeking to avoid the political and economic costs associated with the establishment of permanent US bases in other countries in favour of more flexible arrangements that guarantee the US military access to critical infrastructure in times of crisis. In some ways this may make considerable sense for China, especially in avoiding the high political costs that would likely be associated with establishing a permanent naval presence in the Indian Ocean. However, its practical value would be very much dependent on the quality and reliability of China's security relationships in the region. Such a strategy would require China to enter into agreements with host countries that allow for PLA Navy vessels to obtain logistical support when required. Indeed, Chinese vessels regularly use the ports of Djibouti, Salalah (in Oman) and Port Victoria (Seychelles) for logistical support of their anti-piracy deployment in the Arabian Sea (Kostecka, 2010). But a 'places not bases' strategy would only by successful if it provided Beijing with a reasonable degree of certainty that facilities would be available to the PLA Navy in the event of an acute crisis or conflict. The question therefore becomes: what countries in the Indian Ocean region would be willing to host Chinese vessels in an acute crisis, including one that involved India or the United States?

In contrast to these debates about China's intentions, Beijing argues that the various port projects in the Indian Ocean region are purely commercial in nature. Indeed, although the PLA Navy has been deployed on anti-piracy duties in the Arabian Sea since 2008, Beijing has been careful to minimise any overt military presence in the Indian Ocean and has flatly denied that it has any intention to establish any military bases in the region (The Hindu, 2012). Since late 2013, Beijing has also promoted its 'Maritime Silk Route' (MSR) initiative as an alternative narrative to the String of Pearls. Details remain sketchy, but the proposal appears to envisage a China-centric system of ports, infrastructure projects and special economic zones in Southeast Asia and the northern Indian Ocean. While much of public discussion to date has focused on ports and infrastructure, probably of greater significance is the development of new production and distribution chains across the region, with China at its centre. If implemented, the initiative would no doubt bind countries in the northern Indian Ocean much closer to the Chinese economy. The implications of the initiative for Indian Ocean security are not yet clear.

\section{The development of overland connections to the Indian Ocean}

China is also seeking to mitigate its strategic vulnerability in the Indian Ocean through developing new overland connections to the Indian Ocean through Myanmar and Pakistan. China has had most success in developing connections through Myanmar, including recently completed oil and gas pipelines between the new deep-water port of Kyaukpyu in Myanmar and China's southern Yunnan province. The decision to build the oil pipeline, in particular, was heavily influenced by Beijing's concerns over the Malacca 
Dilemma, although when examined in detail, some of these arguments seem questionable (Kong, 2010). But the strategic value of Kyaukpyu port is also severely limited by the lack of road and rail links to China. The Kyaukpyu corridor was intended to include a $1200 \mathrm{~km}$ railway to the Chinese city of Kunming at a cost of US\$20 billion. The Myanmar government has recently had second thoughts about the project, particularly over the strategic implications of Chinese control over the railway. There are also growing reservations in China about proceeding with such a major project in the 'China-unfriendly' environment in Myanmar (Sun, 2014).

China's other grand Indian Ocean corridor project is the BCIM project, which would involve building a road and manufacturing corridor from Kunming to Calcutta, via Myanmar, India's northeast states and Bangladesh, at a claimed cost of US\$20 billion. China has also mooted plans to improve transport connectivity between its western Xinjian province and the Arabian Sea through Pakistan, through the development of a so-called China-Pakistan Economic Corridor between Gwadar and Kashgar in the western Chinese province of Xinjiang, at an expected cost of US\$18 billion (Mohan, 2013). This would include improved road/rail links to Karachi and a proposed oil pipeline and road/ rail link to Gwadar. But these links would traverse regions of Pakistan where there are significant security risks, which makes it difficult to envisage that a dependable large-scale corridor could be established to Gwadar, at least in the current security environment.

The trans-Myanmar and trans-Pakistan projects are part of Beijing's 'bridgehead strategy' of turning Yunnan and Xinjiang provinces into gateways for economic engagement with the Indian Ocean. It is intended to develop a series of overland pathways to the Indian Ocean and using Yunnan as a 'base' facing South Asia and Southeast Asia to support export processing (Liu, 2013). Xinjiang province in western China will act as a bridgehead for connections with Central Asia and Pakistan. The projects, if completed, would likely have major economic and strategic implications for China's role in the region. The new connections could stimulate considerable economic development in the land-locked provinces of Xinjiang, Tibet and Yunnan, and would also likely lead to an expansion of China's economic and political influence in their host states, Pakistan and Myanmar, and other neighbouring states. As a result, some of China's partners are nervous about the strategic implications. Myanmar has blocked some proposals due to concerns about their implications for China's influence in the country. Some in Delhi fear that these new connections will challenge India's interests in the region and that the BCIM proposal could even threaten India's national cohesion by integrating India's estranged northeastern states into the Chinese economy.

However, the extent to which these new connections may ultimately mitigate China's strategic vulnerability in the Indian Ocean can be overstated. The KyaukpyuKunming oil pipeline, for example, may only account for some $6.7 \%$ of China's total oil imports in 2015 and 3.4\% by 2030 (Erickson \& Collins, 2010, pp. 91-92). China's ability to rely on the Kyaukpyu and Gwadar pipelines as an alternative to shipping oil through the Malacca Strait would be moot if Chinese tankers were intercepted in, say, the Persian Gulf or the Arabian Sea and the pipelines themselves would be highly vulnerable to being cut by precision strikes or attack by local insurgents.

An unintended consequence of these linkages, if fully developed, may be to give Beijing a much greater stake in the internal security of Pakistan and Myanmar, perhaps not necessarily to China's benefit. Beijing has historically been able to maintain good relations with Pakistan and Myanmar while avoiding becoming involved in their dire internal security problems, but this may become difficult to sustain. China has already 
had to deploy security forces in Pakistan-administered Kashmir near the Chinese border to provide security for its construction and maintenance workers from attacks by Islamic and tribal groups (Harrison, 2010). ${ }^{3}$ China could easily find itself called upon to secure a much larger corridor extending across much of the length of Pakistan. Similarly, China could also find itself with a stake in Myanmar's intractable domestic insurgencies in the event that major investments are threatened. The prospect of deployments of Chinese forces to protect Chinese interests would have considerable implications for the region.

But the most immediate effect of these projects will likely be economic. The establishment of development corridors across Myanmar and Pakistan would have major implications for Chinese interests through the entire country. Pakistan's leaders are apparently enthusiastic about it, while Myanmar has been more circumspect about the growth in Chinese influence. Popular reactions against Chinese developments elsewhere in Myanmar indicate that there are significant risks for China.

\section{A contest for influence}

This author has previously argued that, contrary to some of the rhetoric, no security dilemma exists between India and China in respect of the naval balance in the Indian Ocean within the meaning of international relations theory (Brewster, 2014b). A 'security dilemma', as posited by theorists such as Robert Jervis (Jervis, 1978), would require each of India and China to be realistically concerned that the other is taking actions that may give a strategic advantage over it so as to create a threat (and not, for example, merely seeking to mitigate an existing strategic disadvantage). As noted above, there is little evidence that China could realistically gain a strategic advantage over India in the Indian Ocean in the foreseeable future, at least in the maritime realm. But while the concept of a 'security dilemma' may not be entirely useful in understanding the dynamics of competition between India and China in the Indian Ocean, it does not mean that there is not a very keen contest for influence between India and China in the Indian Ocean: for India to maintain its considerable geostrategic advantage, and for China to partially mitigate its disadvantage. This is currently being played out in a jostle for influence between India and China throughout the region.

As discussed above, the PLA Navy exercise in January 2014 highlighted not only China's geographic isolation from the Indian Ocean but also the shallowness of its security relationships. Although China's relationships in the region are undoubtedly growing, there are few countries in the Indian Ocean region that would realistically consider China as a key security provider. Indeed, the contrast between the Milan naval exercise conducted by India in February 2014 and the unnamed Chinese naval exercise conducted a few days earlier could not have been greater in terms of regional relationships. The Chinese deployment was unilateral and the PLA Navy vessels received no support from any neighbouring states. In contrast, India's Milan exercise involved vessels from 16 guest navies and coastguards from across the Indo-Pacific. The exercise series is not primarily intended for practising technical skills, but rather is focused on building confidence and relationships among the military maritime community of participating states. The exercise is an expression of India's success in demonstrating strategic leadership as it grows as a credible power.

The symbolism of Milan was reinforced a few weeks later with the announcement by India's National Security Advisor, Shiv Shankar Menon, that the Indian Ocean island states of Seychelles and Mauritius would be joining India's existing naval arrangement 
with Sri Lanka and the Maldives in a new Indian Ocean security grouping that some have called the 'IO-5' (The Hindu, 2014). India has held joint naval exercises with Sri Lanka for some years and these have been expanded to trilateral exercises with the Maldives Coast Guard. The proposed IO-5 arrangement has not yet been implemented, and it is not clear whether it would go much beyond meetings of respective national security advisors to include operational cooperation. 4 But such an arrangement, if implemented, would represent an important development in regional security architecture and would represent the first time that India has explicitly taken a security leadership role in the Indian Ocean beyond South Asia. Importantly, in announcing this arrangement, Menon also fore-shadowed that in future similar arrangements may be replicated with Bay of Bengal states.

These developments can be seen as a manifestation of the 2013 announcement by Indian Prime Minister Manmohan Singh that henceforth India should be seen as a 'net security provider to the region' (The Hindu, 2013). But while there appears to be a growing recognition and acceptance of India's role as a regional security provider, its role in different parts of the Indian Ocean region is uneven. In October 2014, Delhi commenced an unusual whole-of-government review of its Indian Ocean strategy in an attempt to develop a coordinated approach to defence and commercial relationships in the region (Taneja, 2014). India's has long had close security relationships with the Indian Ocean island states. In the eastern Indian Ocean, India has had growing security relationships with ASEAN countries and Australia for some years (Brewster, 2013) and the Bay of Bengal has now become a particular area of focus (Taneja, 2014). In the western Indian Ocean, India also has growing security relationships with some smaller Arab states (such as Oman and UAE), but its overall security role in the Persian Gulf remains somewhat constrained (Brewster, 2014a). Overall, the United States remains the most important security partner for most states in the Indian Ocean region and is likely to remain so for some time to come, although Washington is generally happy to see India further develop its role as a regional security provider.

China's economic influence is also growing throughout the Indian Ocean region, in line with its rise as a world economic power. China is now the biggest trading partner for many states in the Indian Ocean region and is a major source of investment, especially in infrastructure. Several countries also seek to use China as a partial balance or hedge in their political and economic relations with bigger powers such as the United States and India (Kaplan, 2009; Mohan, 2012). While many, if not all, states in the region are eager for more Chinese trade and investment, with some exceptions there is as yet little indication that these economic relations are being translated into substantive security or defence relationships, particularly in the maritime realm. Smaller states, including Indian Ocean islands such as Sri Lanka, Maldives and Seychelles from time to time seek to play the 'China card' in an effort to extract more concessions or economic assistance from India. For some, such as Myanmar, Bangladesh and Sri Lanka, China is also a major source of arms. This is driven by several factors including the relative price of Chinese defence technology (a very important factor for most Indian Ocean states), the existence of international arms embargos (which at times have affected Myanmar and Sri Lanka) and balancing considerations (which at times have been important considerations for states such as Myanmar and Bangladesh).

But concerns that arms supply relationships will be translated into substantive defence relationships are yet to be proved. Until recently, there were widespread concerns that the apparently close economic, political and arms supply relationship between China and the 
Myanmar military regime would be translated into a de facto alliance. Through the 1990s, Chinese companies were involved in the development or upgrading of several ports in Myanmar and the construction of a signals intelligence facility in the Bay of Bengal, which many analysts claimed were part of China's String of Pearls strategy (Malik, 2011). But while Myanmar was happy to accept Chinese arms and investment it apparently had no intention of strategically subordinating itself to Beijing (Myint-U, 2011). Indeed, the Indian Navy publicly conceded in 2005 that there were no Chinese naval bases anywhere in Myanmar (Asian Defence Journal, 2005). Beginning in 2011, Myanmar has partly distanced itself from China. The cancellation of the huge Myitsone dam project, which had been sponsored by China and was intended to be a major source of electricity to southern China, 'fundamentally shook Chinese leaders' trust and confidence in Myanmar as a partner' (Sun, 2012). This was followed soon after by Myanmar's political opening towards the United States and India and the partial liberalisation of its political system, all of which has substantially reduced China's influence in the country. These developments may have been the result of an overestimation by China of its political and economic influence. In any event, the deterioration of its relationship with Myanmar probably represents a significant set-back for China in the Indian Ocean region.

Similarly, despite concerns about China's role as the major supplier of weapons and training to the Bangladesh armed forces (see, for example, Sitaraman, 2013), there are no reliable indicators that this has been translated into a substantive defence relationship. There is no operational coordination between the Bangladeshi and Chinese armed forces, they hold no substantive bilateral military exercises and nor is there any indication that Bangladesh would be willing to host any Chinese naval or other military presence (Kabir, 2014; Samaranayake, 2012). The recent cancellation by Bangladesh of an order for two Chinese Ming class submarines and their replacement with an order for Russian submarines is a clear indication that Bangladesh will shop around for the best deal in equipment (Gupta, 2014). Dhaka has also made it clear that its preference is to have to new deep-water ports at Sonadia or elsewhere developed by a consortium of international investors not dominated by China.

But China's influence is growing elsewhere. Pakistan is China's principal partner and de facto ally in the region, and the relationship is growing closer. Since the 1960s, China has established itself as a major supplier of arms to Pakistan and provided it with significant strategic support against India. The so-called 'all weather friendship' with Pakistan (alongside its relationship with North Korea) is the closest China has come to a long-term alliance. The China factor has played a significant role in limiting India's strategic options with Pakistan, largely through perceived threats on the Sino-Indian border in the Himalayas and through facilitating the proliferation of nuclear weapons and missiles to Pakistan. As noted above, in recent years, Pakistan has indicated its readiness to host Chinese naval facilities at the port of Gwadar, although Beijing has responded cautiously to these suggestions. China may have good reasons to be cautious about the parameters of its relationship with Pakistan. While the United States is able to maintain freedom of navigation in the Persian Gulf and the Strait of Hormuz, China may as yet have little reason to establish a military presence at Gwadar.

Sri Lanka could also become an important strategic partner. Since at least 2009, Colombo has been keen to cultivate Beijing as an economic partner to drive development and as a diplomatic partner to help fend off international pressure over human rights issues. Sri Lanka has now cast itself as China's primary partner in the MSR initiative. 
Under the Rajapaksa Government there were indications of Sri Lanka's willingness to give China access to military-related facilities. In October 2014, apparently as part of the MSR initiative, it was revealed that China has been invited to take over management of a new and enlarged Phase II development of Hambantota port, which will include berths dedicated for Chinese use. The previous government also proposed to establish a Chinese-run facility in northern Sri Lanka to support the Sri Lankan Air Force. Concerns about a possible Chinese military presence in Sri Lanka were also heightened by visits in September and October 2014 of Chinese submarines to a new Chinese-built port in Colombo (Brewster, 2014c). But these developments may be reversed following the election of President Sirisena in January 2015 on a platform of placing the relationship with China on a more 'balanced' footing. While Sri Lanka may find a partnership with China as providing useful economic and political benefits, it is difficult to envisage it changing India's geostrategic domination of that island.

\section{Conclusion}

China suffers from fundamental strategic vulnerability in the Indian Ocean and its ability to mitigate that vulnerability is limited. For the foreseeable future, China is likely to have only a very limited ability to project power into the Indian Ocean. The development of China's putative 'Pearls' and tenuous overland transport links would do little to mitigate these vulnerabilities. Indeed, it is difficult to conceive how China could ultimately unable to protect the entirety of its Indian Ocean SLOCs from India in the event of conflict between the two. Although India's overall military capabilities are considerably less than China's, the geographic centrality of the Indian subcontinent, which sits astride the key sea lanes that cross the northern Indian Ocean, give it considerable natural advantages.

China's strategic disadvantages in the Indian Ocean are only further reinforced by the strategic alignments of the Indian Ocean states, which largely tend towards the United States and/or India. After decades of avoiding security alignments in the Indian Ocean region, partly on ideological grounds, India is now in the process of building regional alignments in which it takes a leadership role.

China's economic influence in the region is undoubtedly growing. While this carries with it a degree of political influence, it would be a mistake to assume that this necessarily automatically translates into the security realm. While there is considerable jostling among China, India and the United States to develop influence in the Indian Ocean region, no Indian Ocean state (with the exception of Pakistan) would currently be entitled to seriously consider China as a major security provider. Most states are more or less following the experiences of other Asian states in developing their economic relationships with China while hedging their bets in terms of security. No doubt China's strategic role will continue to develop in the Indian Ocean, but it is as yet difficult to envisage China overcoming its geostrategic vulnerabilities in the region. Those concerned about the security dynamics of the Indian Ocean region need to take into account the fundamental vulnerability faced by China.

\section{Disclosure statement}

No potential conflict of interest was reported by the author. 


\section{Notes}

1. See, also to similar effect, Chinese media reports quoted in US-China Economic and Security Review Commission Staff Report, 2014. The First and Second Island Chains are notional strings of islands running from Japan through the western Pacific and Southeast Asia that could be used to 'cut off' China's access to the ocean. Indonesia actually sits in the notional Second Island Chain.

2. By sea and air and potentially also by land-based anti-ship cruise missiles deployed at the choke points.

3. Chinese troops likely numbered in the hundreds and not the thousands as reported in the New York Times.

4. The implementation of the IO- 5 arrangement has been slowed by Colombo, apparently because of political irritations with Mauritius. Confidential interview by author with a senior Sri Lankan government official, October 2014. Colombo's position may well change following the election of a new president in January 2015.

\section{References}

Asian Defence Journal. (2005). Interview with Admiral Arun Prakash, Chief of Naval Staff, Indian Navy, October, p. 22.

Brewster, D. (2013). India's defence strategy and the India-ASEAN relationship. In Ajaya Kumar Das (Ed.), India-ASEAN defence relations RSIS monograph No. 28. 125-146. Singapore: S. Rajaratnam School of International Studies.

Brewster, D. (2014a). India's ocean: The story of India's bid for regional leadership. London: Routledge.

Brewster, D. (2014b). Beyond the string of pearls: Is there really a Sino-Indian security Dilemma in the Indian Ocean? Journal of the Indian Ocean Region, 10(2), 133-149. doi: 10.1080/ 19480881.2014.922350

Brewster, D. (2014c, November 26). Sri Lanka tilts to China. East Asia Forum. Retrieved from http://www.eastasiaforum.org/2014/11/26/sri-lanka-tilts-to-beijing/

CCTV.com. (2014, February 2). Combat vessels training for quick response in electronic war. CCTV. com. Retrieved March 6, 2014, from http://english.cntv.cn/program/newsupdate/20140202/ 100068.shtml

Erickson, A. S., \& Collins, G. B. (2010). China's oil security pipe dream. Naval War College Review, 63(2), 91-92.

Gupta, J. (2014, November 7). Bangladesh turns to Russia for submarines. The Times of India.

Harrison, S. (2010, August 26). China's discreet hold on Pakistan's Northern Borderlands. New York Times.

Holmes, J. R. (2012). Inside, outside: India's 'exterior lines' in the South China sea. Strategic Analysis, 36, 358-363. doi: 10.1080/09700161.2012.670483

Holmes, J. R., \& Yoshihara, T. (2008). China's naval ambitions in the Indian Ocean. Journal of Strategic Studies, 31, 367-394. doi: 10.1080/01402390802024700

Indian Navy. (2007). Freedom to use the seas: India's maritime military strategy. New Delhi: Integrated Headquarters, Ministry of Defence (Navy).

Jervis, R. (1978). Cooperation under the security dilemma. World Politics, 30, 167-214. doi: $10.2307 / 2009958$

Kabir, A. (2014, January 3). China making a play at Bangladesh? Forbes.

Kaplan, R. D. (2009). Center stage for the twenty-first century. Foreign Affairs, pp. 16-29. Kong,

B. (2010, September). The geopolitics of the Myanmar-China oil and gas pipelines. In M. E. Herberg (Ed.), Pipeline politics in Asia: Energy nationalism and energy markets (pp. 55-66). (NPB Special Report No.2).

Kostecka, D. J. (2010). The Chinese Navy's emerging support network in the Indian Ocean. China Brief, 10(15), 3-5.

Liu Jinxen. (2013, November 16). China's bridgehead strategy and Yunnan province. East by Southeast. Retrieved from http://www.eastbysoutheast.com/chinas-bridgehead-strategyyunnan- province/\#comments

Maitra, R. (2005, October 19). India bids to rule the waves. Asia Times. 
Malik, M. (2011). China and India: Great power rivals. Boulder, CO: First Forum Press. Medcalf,

R. (2014, February 7). China makes statement as it sends naval ships off Australia's maritime approaches. Lowy Interpreter. Retrieved March 6, 2014, from http://www.lowyinterpr eter.org/post/2014/02/07/China-makes-statement-as-it-sends-naval-ships-off-Australiasmaritime- approaches.aspx

Mohan, C. R. (2012) Samudra manthan: Sino-Indian rivalry in the Indo-Pacific. Washington, DC: Carnegie Endowment for International Peace.

Mohan, C. R. (2013, July 10). Kashgar corridor. Indian Express.

Myint-U, T. (2011). Where China meets India: Burma and the New Crossroads of Asia. London: Faber and Faber.

Perrett, B. (2011, October 14). China expands its military reach. Aviation Week \& Space Technology. p. 20.

Ramachandran, S. (2007, March 13). China moves into India’s back yard. Asia Times.

Singh, Z. D. (2013, August 7). China deterrence cannot come from Navy. The Hindu.

Sitaraman, S. (2013, July 19). Is South Asia moving into the Chinese orbit and setting off alarm bells in New Delhi? Foreign Policy Journal.

Smaranayake, N. (2012, September). The long littoral project: Bay of Bengal. Center for Naval Analyses.

Storey, I. (2006). China’s Malacca dilemma. Jamestown foundation china Brief, 6(8).

Sun, Y. (2012). China's strategic Misjudgement in Myanmar. Journal of Current Southeast Asian Affairs, 31(1), 73-96.

Sun, Y. (2014, August 14). China, Myanmar: Stop that train. Asia Times.

Taneja, K. (2014, November 8). India to reset strategic policy for region. Sunday Guardian (Delhi). The

Hindu. (2012, September 4). China has no plan for Indian Ocean military bases. The Hindu. The Hindu.

(2013, May 23). India well-positioned to become net security provider in our region and beyond: PM. The Hindu.

The Hindu. (2014, March 7). Seychelles, Mauritius join Indian Ocean maritime security group. The Hindu.

US-China Economic and Security Review Commission Staff Report. (2014, March 14). China's Navy extends its combat reach to the Indian Ocean. Retrieved August 30, 2014, from http:// www.uscc.gov/Research/china\%E2\%80\%99s-navy-extends-its-combat-reach-indian-ocean

US Congressional Research Service. (2014, 5 August). China naval modernization: Implications for U.S. Navy capabilities - Background and issues for congress. Washington D.C: Congressional Research Service, 2014.

US Department of Defense. (2012). Annual report to congress: Military and security developments involving the People's Republic of China. Washington D.C: Office of the Secretary of Defense, 2012.

Wroe, D. (2014, February 15). China’s military might is Australia's new defence reality. Sydney Morning Herald.

Yung, C. D., \& Rustici, R. with Kardon, I \& Wiseman, J. 2010. China's out of area naval operations: Case studies, trajectories, obstacles, and potential solutions. Washington, DC: National Defense University Press.

Zeenews.com. (2009, August 13). China afraid of India's naval presence in the Ocean. Zeenews.com. 